\title{
Combining Aldolases and Transaminases for the Synthesis of 2-Amino-4-hydroxybutanoic Acid
}

\author{
Karel Hernandez,,$^{\dagger}$ Jordi Bujons, ${ }^{\dagger}$ Jesús Joglar, $^{\dagger}$ Simon J. Charnock, ${ }^{\ddagger}$ Pablo Domínguez de María, ${ }^{\S}$ \\ Wolf Dieter Fessner," and Pere Clapés*, †⿺廴( \\ ${ }^{\dagger}$ Dept. Chemical Biology and Molecular Modeling, Instituto de Química Avanzada de Cataluña-IQAC-CSIC, Jordi Girona 18-26, \\ 08034 Barcelona, Spain \\ ${ }^{\ddagger}$ Prozomix Ltd., Station Court, Haltwhistle, Northumberland NE49 9HN, U.K. \\ ${ }^{\S}$ Sustainable Momentum S.L. Ap. Correos 3517, 35004 Las Palmas de Gran Canaria, Spain \\ "Institut für Organische Chemie und Biochemie, Technische Universität Darmstadt, Alarich-Weiss-Straße 4, 64287 Darmstadt, \\ Germany
}

\section{Supporting Information}

ABSTRACT: Amino acids are of paramount importance as chiral building blocks of life, for drug development in modern medicinal chemistry, and for the manufacture of industrial products. In this work, the stereoselective synthesis of $(S)$ - and (R)-2-amino4-hydroxybutanoic acid was accomplished using a systems biocatalysis approach comprising a biocatalytic one-pot cyclic cascade by coupling of an aldol reaction with an ensuing stereoselective transamination. A class II pyruvate aldolase from E. coli, expressed as a soluble fusion protein, in tandem with either an $S$ - or $R$-selective, pyridoxal phosphate dependent transaminase was used as a catalyst to realize the conversion, with formaldehyde and alanine being the sole starting materials. Interestingly, the class II pyruvate aldolase was found to tolerate formaldehyde concentrations of up to $1.4 \mathrm{M}$. The cascade system was found to reach product concentrations for $(S)$ - or $(R)$-2-amino-4-hydroxybutanoic acid of at least $0.4 \mathrm{M}$, rendering yields between $86 \%$ and $>95 \%$, respectively, productivities of $>80 \mathrm{~g} \mathrm{~L}^{-1} \mathrm{~d}^{-1}$, and ee values of $>99 \%$.

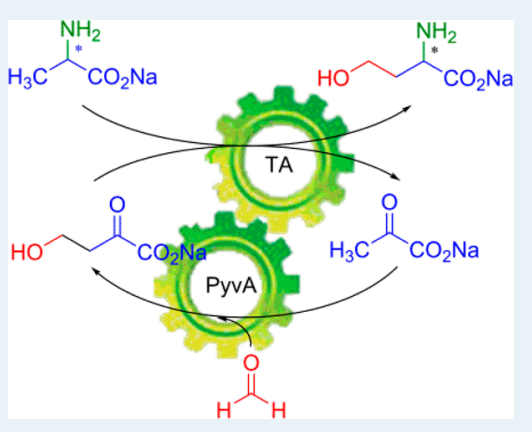

KEYWORDS: biocatalysis, substrate cycling, green chemistry, aldolases, transaminases

\section{INTRODUCTION}

Amino acids are compounds of paramount importance for living organisms, as building blocks for protein and peptide synthesis, chiral intermediates in modern medicinal chemistry, and valuable building blocks in the manufacture of industrial products. ${ }^{1}$ An interesting example is 2-amino-4-hydroxybutanoic acid (i.e., homoserine), a noncanonical amino acid homologous to L-serine by insertion of an additional methylene unit into the side chain and an important metabolic intermediate. ${ }^{2}$ It also constitutes a valuable building block for the synthesis of 3-hydroxypropionic acid and 1,3-propanediol, important starting materials in the manufacture of biocompatible plastic and polytrimethylene terephthalate (PTT), among other industrial products. ${ }^{3}$ Furthermore, L-homoserine lactone derivatives are useful compounds for studying the quorum sense signaling (QSS) mechanism (i.e., cell to cell communication) and indeed as potential QSS inhibitors in new antimicrobial strategies against pathogenic Gram-negative and Gram-positive bacteria (antivirulence intervention strategy). ${ }^{1 \mathrm{c}, 4}$

The industrial production of amino acids, including Lhomoserine, has to date predominantly been achieved via microbial fermentation (i.e., cell factories). ${ }^{2 c, e, 3 b, 5}$ However, drawbacks of this technology include the unpredictable physiological behavior of cellular production systems upon engineering of elusive metabolic pathways and a rather limited flexibility toward the synthesis of structurally diverse nonnatural products. ${ }^{6}$ In contrast, isolated enzyme systems for in vitro production (i.e., systems biocatalysis) ${ }^{6}$ offer simplicity and adaptability, because these are unrestrained by problems arising from the intricate nature of cellular metabolic pathways. In addition, such systems benefit from the ever-increasing number and diversity of available native enzymes, as well as their engineered variants, active toward a broad variety of substrate analogues. From a practical point of view, in vitro systems are easier to manage and monitor because of their lower complexity. $^{5 \mathrm{~b}, 6,7}$ Needless to say, the concept of systems biocatalysis shares all the synthetic and environmental advantages that have become the hallmark of commercial biocatalytic processes.

\section{RESULTS AND DISCUSSION}

A stereoselective biocatalytic one-pot cascade methodology ${ }^{8}$ was envisioned for the synthesis of both enantiomeric forms of homoserine ( $S-5$ and $R-5)$, comprising cyclic aldol addition and

Received: November 8, 2016

Revised: January 12, 2017

Published: January 18, 2017 
subsequent reductive amination reactions, with effective pyruvate (2) recycling (Scheme 1): (i) aldol addition of 2 to

Scheme 1. One-Pot Biocatalytic Cascade Synthesis of $S-5$ or $R-5$ with Substrate Recycling, Starting from Formaldehyde (1) and $S-4$ or R-4, Respectively ${ }^{a}$

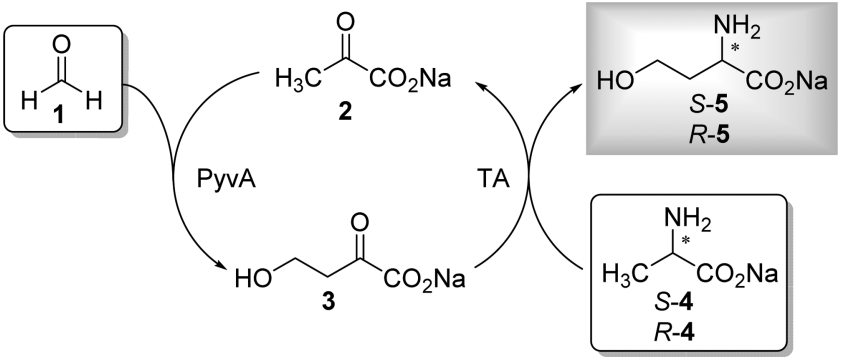

${ }^{a}$ Abbreviations: PyvA, pyruvate aldolase; TA, $S$ - or $R$-selective transaminase.

formaldehyde (1); (ii) reductive amination of aldol adduct 3, using alanine ( $S-4$ or $R-4)$ as the amine donor, to produce $S-5$ or $R-5$, respectively, with concomitant release of 2 , to be recycled by recurrent aldol addition, thus favoring the reductive amination equilibrium toward $\mathbf{5}$. Notably, by applying such a synthetic cycle the approach can be implemented with readily available and inexpensive substrates (in this example, alanine and formaldehyde), while requiring just catalytic amounts of pyruvate to trigger the overall pathway.

A viable commercial process requires an aldolase tolerating high concentrations of aldehyde substrates, which are strongly electrophilic, a transaminase that is active and selective under similar reaction conditions, and cost effectiveness for the overall biotransformation.

Biochemical studies have been reported for the in vitro enzymatic aldol addition of pyruvate to formaldehyde using a mammalian hydroxyoxobutyrate aldolase (EC 4.1.2.1), which is a class I aldolase that acts via covalent substrate activation by Schiff base formation at a lysine residue in the active site. However, such enzymes easily become inactivated by nonspecific reactions involving the essential lysine residue in the presence of strong electrophiles, such as formaldehyde, even at low concentrations. ${ }^{10}$ In contrast, class II pyruvate aldolases utilize a divalent metal ion as an essential cofactor to promote the enolization of the pyruvate nucleophile and do not possess a sensitive active-site lysine and thus appear potentially more suitable for the target reaction. ${ }^{11}$ Among them, YfaU (EC 4.1.2.53) was selected from the genome of E. coli K-12. ${ }^{12} \mathrm{YfaU}$ is known to catalyze the reversible cleavage of pyruvate from 2keto-3-deoxy-L-rhamnonate, 2-keto-3-deoxy-L-lyxonate, and 4hydroxy-2-ketopentanoic acid to furnish L-lactaldehyde, hydroxyethanal, and ethanal, respectively. Nevertheless, hitherto reported studies regarding this enzyme concern fundamental biochemical studies only with little or no direct connection to any potential synthetic utility. ${ }^{12}$ The $r h m A$ gene encoding the $\mathrm{YfaU}$ protein was initially cloned in the pQE40 expression vector (Qiagen) to generate a fusion protein with very soluble dihydrofolate reductase (DHFR) at the $\mathrm{N}$ terminus. ${ }^{13}$ However, under these conditions it was found that DHFR$\mathrm{YfaU}$ was mostly expressed as insoluble inclusion bodies (Figure S2A in the Supporting Information). This problem was circumvented by expressing $\mathrm{YfaU}$ as a fusion protein with maltose binding protein (MBP) from E. coli at the $\mathrm{N}$ terminus
(MBP-YfaU), along with a $\mathrm{His}_{6}$ tag for affinity purification (Figure S2B) (yield $180 \mathrm{mg} \mathrm{L}^{-1}$ of MBP-YfaU of bacterial growth medium). While the structure of native $\mathrm{YfaU}$ is hexameric (a trimer of dimers, the dimer being the minimal repetitive unit), ${ }^{12 a}$ the MBP-YfaU fusion protein only forms a dimer, as determined by gel filtration (see the Supporting Information). It appears that the MBP fusion prevented the hexameric biological assembly but not functional dimer formation. Recombinant MBD-YfaU apparently exhibited a high affinity for its natural $\mathrm{Mg}^{2+}$ cofactor from the bacterial growth medium, which predominantly remained bound in the active site even subsequent to purification via IMAC and dialysis against $10 \mathrm{mM} \mathrm{Na}^{+}$phosphate buffer, $\mathrm{pH}$ 7.0 (MBP$\mathrm{YfaU}\left(\mathrm{Mg}^{2+}\right) 2.5 \mathrm{U} \mathrm{mg}^{-1}$; see Table S1 in the Supporting Information).

NMR data confirmed that the enzymatic aldol addition of 2 to $\mathbf{1}$ yielded the desired intermediate 3 . Remarkably, when the best reaction conditions were screened for the critical carboligation step, MBP-YfaU $\left(\mathrm{Mg}^{2+}\right)$ retained activity at substrate concentrations of $>1 \mathrm{M}$ for both 1 and $2\left(\mathrm{IC}_{50}[\mathbf{1}]\right.$ $=1.4 \mathrm{M})($ Figure 1$)$, leading to an outstanding productivity of<smiles>CC(=O)OOCCC(=O)N[13CH]=C[13CH]=O</smiles>

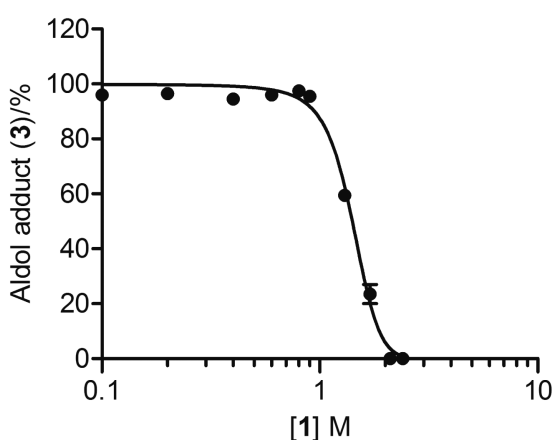

Figure 1. Influence of the concentration of $\mathbf{1}$ on the yield of 3 in the aldol addition of 2 to 1 catalyzed by MBP-YfaU $\left(\mathrm{Mg}^{2+}\right)$. Conditions: $[2]=[1], 50 \mathrm{mM} \mathrm{Na}^{+}$phosphate buffer, $\mathrm{pH} 7.0$, and $24 \mathrm{~h}$ of reaction (experimental details are given in the Supporting Information).

$140 \mathrm{~g} \mathrm{~L}^{-1} \mathrm{~d}^{-1}$ of intermediate 3 at $[1]=[2]=1 \mathrm{M}$ even under preliminary nonoptimized conditions. This observation was very surprising, given that strongly electrophilic aldehydes such as $\mathbf{1}$ often denature enzymes even at low concentration.

Incubation with other divalent cations showed that MBP$\mathrm{YfaU}$ as a ligand with $\mathrm{Co}^{2+}$ or $\mathrm{Ni}^{2+}$ exhibited $\sim 3$ - or 2 -fold higher activity (see Table $\mathrm{S} 1$ and accompaying discussion in the Supporting Information), respectively. As observed for other class II aldolases, some nonphysiological metals, particularly $\mathrm{Co}^{2+}$ and $\mathrm{Ni}^{2+}$, can improve the activity and/or even catalyze side reactions by taking advantage of the reactive intermediates generated by the catalytic machinery. ${ }^{12 a, 14}$ No product formation was observed in control experiments performed under the same conditions without enzyme or in the presence of EDTA. Control reactions using bovine serum albumin as a noncatalytic protein in the presence of $\mathrm{Mg}^{2+}$ or $\mathrm{Ni}^{2+}$ resulted in a background level of $<0.5 \%$ conversion after $24 \mathrm{~h}$. 
In addition, the formation of the byproduct 6 was also observed (Scheme 2), which arose from the subsequent

Scheme 2. Sequential Catalysis by MBP-YfaU $\left(\mathrm{Mg}^{2+}\right)$ and $\mathrm{Ni}^{2+}$ or $\mathrm{Co}^{2+}$ in the Aldol Addition of 2 to 1 and Subsequent Aldol Addition of 3 to a Second Equivalent of 1 To Yield 6

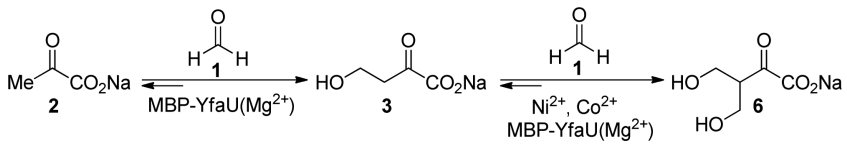

addition of product 3 to a second equivalent of $\mathbf{1}$. For example, under batch conditions, with a 1:1 molar ratio of substrates and MBP-YfaU $\left(\mathrm{Mg}^{2+}\right)$ as biocatalyst (specific conditions: $[2]=[1]$ $=1 \mathrm{M}, 50 \mathrm{mM} \mathrm{Na}{ }^{+}$phosphate buffer, $\mathrm{pH} 7, \mathrm{MBP}-\mathrm{YfaU}\left(\mathrm{Mg}^{2+}\right)$ (31 mg, $77 \mathrm{U}, 10 \mathrm{U} \mathrm{mL}^{-1}$ ) and $24 \mathrm{~h}$ of reaction at $25^{\circ} \mathrm{C}$ ), a mixture of 3 and 6 in a ratio of 9:1 (by NMR analysis) was observed. Interestingly, it was found that this side reaction was mainly catalyzed by $\mathrm{Ni}^{2+}$ and $\mathrm{Co}^{2+}$ ions themselves, with no 6 produced with just $\mathrm{Mg}^{2+}$ present (Figure S7 in the Supporting Information). However, MBP-YfaU $\left(\mathrm{Mg}^{2+}\right)$ did catalyze the secondary reaction, but to a much lower extent $(<10 \%)$ (Figure $\mathrm{S} 6$ in the Supporting Information). Thus, MBP-YfaU $\left(\mathrm{Mg}^{2+}\right.$ or $\mathrm{Zn}^{2+}$ ) species were the most selective biocatalysts toward the synthesis of 3 (Figure S6), with the former being selected for the purpose of this work.

The next step was the stereoselective enzymatic reductive amination of 3 (Scheme 1). To this end, we screened a library of 51 individual pyridoxal phosphate (PLP) dependent transaminases, provided by Prozomix Ltd. as lyophilized crude cell free extracts, using $S-4$ and $R-4$ as amine donors (Figure 2). From the best hits showing high conversion rates

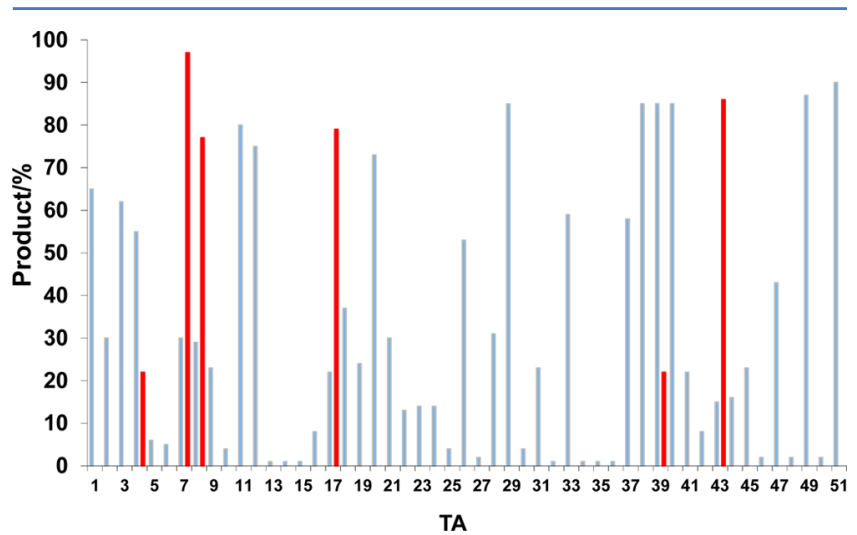

Figure 2. Screening of transaminases (Prozomix) for the reductive amination of 3 to $S-5$ (blue) and R-5 (red) at $24 \mathrm{~h}$ (full conditions are given in the Supporting Information). TA51 corresponds to transaminase from Vibrio fluvialis (supplied by Prozomix Ltd.).

(i.e., $>80 \%$ after $24 \mathrm{~h}$; Figure 2), enzyme TA51 from Vibrio fluvialis (ee > 99\%) was selected for further studies. The thermodynamic equilibrium constant for the desired reaction was 0.77 (see the Supporting Information), which compares favorably with other enzymatic reductive aminations. ${ }^{80,15}$

With a suitable transaminase identified, we next investigated the optimal [2] required for effective substrate cycling within the biocatalytic cascade (Scheme 1 and Figure S10 in the Supporting Information). To trigger the biocatalytic cascade, in principle the initial amount of $\mathbf{2}$ should be kept low to overcome the thermodynamic limitations of the reductive amination. Indeed, a reaction comprising $\leq 0.05 \mathrm{mmol}$ of $2,0.1$ mmol of $S-4$, portionwise addition of $1(0.1 \mathrm{mmol}, 0.0125$ $\mathrm{mmol} \mathrm{h}{ }^{-1}$, eight additions), MBP-YfaU $\left(\mathrm{Mg}^{2+}\right)(10 \mathrm{U})$, and TA51 (2.8 U) successfully demonstrated the recycling of 2 as the deaminated component produced in the transamination.

We next observed that the lower the pyruvate to alanine ratio 2:S-4 (e.g., $\leq 0.5$ ) chosen, the lower the amount of 1 tolerated by the system in each addition (Figure 3). Presumably,

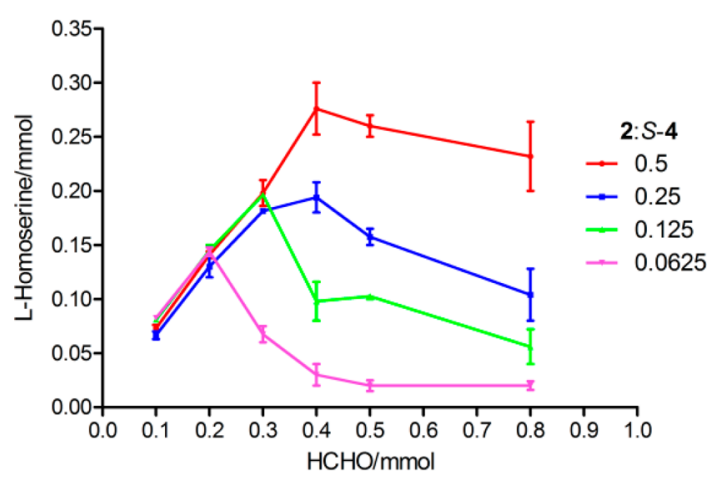

Figure 3. Effect of the total amount of $\mathbf{1}$ added on $S-5$ formed at $24 \mathrm{~h}$ and at different 2:S-4 ratios. Conditions: $S-4(0.1 \mathrm{mmol}), 1$ added portionwise (0.0125-0.1 mmol h $\mathrm{h}^{-1}$, eight additions), with MBP$\mathrm{YfaU}\left(\mathrm{Mg}^{2+}\right)$ and TA51 as biocatalysts. $V=1 \mathrm{~mL}$.

inhibitory or inactivation effects are the most plausible explanation, as indicated by the experiments conducted ad hoc (Figure S11 in the Supporting Information). However, reducing the amount of $\mathbf{1}$ was also found to be detrimental, presumably because of the thermodynamic limitations for the reductive amination that are caused by an excess of unreacted pyruvate.

A kinetic analysis of the compounds that participate in the cascade starting from $\mathbf{2}, \mathbf{S - 4}$, and $\mathbf{1}$ (Figure 4) indicates that (a)

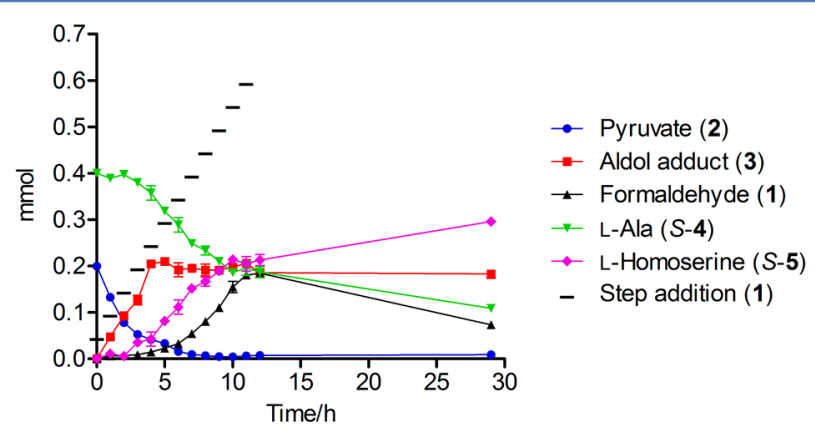

Figure 4. Progress of the biocatalytic cyclic cascade synthesis of $S-5$ with 1 added portionwise. Conditions: $2(0.2 \mathrm{mmol}), S-4(0.4 \mathrm{mmol})$, 1 (12 additions of $0.05 \mathrm{mmol}$ at $1 \mathrm{~h}$ intervals, total $0.6 \mathrm{mmol}$ ), MBP$\mathrm{YfaU}\left(\mathrm{Mg}^{2+}\right)(4 \mathrm{mg}, 10 \mathrm{U})$, and TA51 $(20 \mathrm{mg}, 2.8 \mathrm{U})$ in $50 \mathrm{mM} \mathrm{Na}{ }^{+}$ phosphate buffer, $\mathrm{pH} 7.0, V=1 \mathrm{~mL}$. Samples were taken immediately before the addition of $\mathbf{1}$. Dashes indicate the cumulative addition of $\mathbf{1}$.

the first additions of $\mathbf{1}$ were rapidly converted to $\mathbf{3}$, consuming the starting quantity of pyruvate, (b) $S-5$ was first detected when the aldol adduct reached a level of $\sim 50 \mathrm{mM}(0.05 \mathrm{mmol})$, (c) after that stage, there is an effective recycling of 2 , which favors conversion toward the thermodynamic equilibrium and minimizes TA inactivation by $\mathbf{1}$, (d) 3 accumulated to a final concentration of $\sim 200 \mathrm{mM}(0.2 \mathrm{mmol})$, and (e) under these conditions a $75 \%$ yield of $S-5$ was achieved. Lower yields were obtained (Figure S12A,B in the Supporting Information) when 
less 1 was employed; when a cumulative $0.2 \mathrm{mmol}$ of 1 was added (i.e., effectively performing a one-pot, two-step process with no pyruvate recycling) during a $4 \mathrm{~h}$ reaction, the yield fell to just $30 \%$, whereas with a cumulative $0.4 \mathrm{mmol}$ of 1 over $8 \mathrm{~h}$, the yield was reduced to $56 \%$.

We further tried to optimize the system by investigating the effect of continuous feeding of $\mathbf{1}$, using a syringe pump, on the yield of $S$-5 when using transaminases TA20, TA26, TA39, and TA51 (Table 1). Remarkably, when TA39 was used, the yield

Table 1. Biocatalytic Cyclic Cascade System for $S-5$ and $R-5$ Synthesis $^{a}$

$\begin{array}{crrcl}\text { Prozomix TA } & \text { TA/U } & \mathbf{5} / \% & \text { isolated yield }{ }^{b} / \% & \text { ee/\% }{ }^{c} \\ \text { TA20 } & 12 & \mathrm{npd}^{e} & & \\ \text { TA26 } & 34 & 11 & \mathrm{ni}^{f} & \mathrm{nd}^{g} \\ \text { TA39 } & 7 & 86 & 56 & >99(S) \\ \text { TA51 } & 28 & 64 & 29 & >99(S) \\ \text { TA7 } & 480 & >95 & 64 & >99(R) \\ \text { TA17 } & 1160 & >95 & 59 & >99(R) \\ \text { TA43 } & 460 & >95 & 63 & >99(R)\end{array}$

${ }^{a}$ Conditions: $2(2.1 \mathrm{mmol})$ and $S-4(4.2 \mathrm{mmol})$ in $50 \mathrm{mM} \mathrm{Na}{ }^{+}$ phosphate buffer, $\mathrm{pH} 7.0(7.8 \mathrm{~mL})$, PLP $(10.5 \mu \mathrm{mol})$, MBP$\mathrm{YfaU}\left(\mathrm{Mg}^{2+}\right)(40 \mathrm{mg}, 100 \mathrm{U}), \mathrm{TA}$ (as in the table), and 1 continuously added with a syringe pump $\left(0.57 \mathrm{mmol} \mathrm{h}^{-1}, 0.18 \mathrm{~mL} \mathrm{~h}^{-1}\right.$; total added $18.4 \mathrm{mmol}$ during $15 \mathrm{~h}$ ), reaction time $24 \mathrm{~h}, V=10.5 \mathrm{~mL}$ (detailed conditions are given in the Supporting Information). ${ }^{b}$ The products were isolated as Cbz-L- and Cbz-D-homoserine lactone ( $S-7$ and $R-7$, respectively; see the Supporting Information). ${ }^{c}$ Determined by chiral HPLC (see the Supporting Information). ${ }^{d}$ For unit definition of TA see the Supporting Information. ${ }^{e}$ npd: no product detected. ${ }^{f}$ ni: not isolated. ${ }^{g}$ nd: not determined.

of $S-5$ increased to $86 \%$ ( $e e>99 \%$ by chiral HPLC) with a cumulative formaldehyde addition of $8.4 \mathrm{mmol}$ (Figure 5),

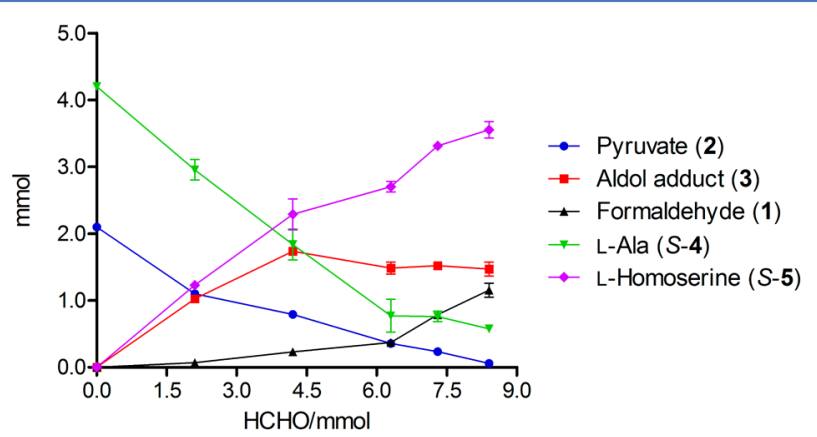

Figure 5. Biocatalytic cyclic cascade system for $S-5$ synthesis with continuous addition of 1 : effect of total 1 added on the reaction mixture composition after $24 \mathrm{~h}$. Conditions: 2 (2.1 mmol), S-4 (4.2 mmol), PLP (10.5 $\mu \mathrm{mol}), \mathrm{MBP}-\mathrm{YfaU}\left(\mathrm{Mg}^{2+}\right)(40 \mathrm{mg}, 100 \mathrm{U}), \mathrm{TA} 39$ $(210 \mathrm{mg}, 7.4 \mathrm{U}), 1$ continuously added with a syringe pump $(0.57$ $\mathrm{mmol} \mathrm{h} \mathrm{h}^{-1}, 0.18 \mathrm{~mL} \mathrm{~h}^{-1}$, and duration $4-15 \mathrm{~h}$ depending on the experiment), $V=10.5 \mathrm{~mL}$ (complete experimental details are given in the Supporting Information).

implying a net quantity of $3 \mathrm{mmol}$ of pyruvate recycled, given that the final amount of 2 was just $0.06 \mathrm{mmol}$. To further demonstrate the utility of this system, the synthesis of $R-5$ was also accomplished in near quantitative yields (ee > 99\%) when TA7, TA17, or TA43 was employed in the presence of $R-4$ as the amine donor.

\section{CONCLUSION}

In summary, we have developed a biocatalytic one-pot cyclic cascade system for the complementary, stereoselective synthesis of both $\mathrm{L}^{-}$and D-homoserine in $86 \%$ and $>95 \%$ yields, respectively, with $>99 \%$ ee each. Differences in the product yields observed could be due to distinct inhibition/deactivation of the transaminases involved in the reaction. Readily available inexpensive starting materials such as formaldehyde and alanine can be used at high concentrations (i.e., $0.8 \mathrm{M}$ ), leading to homoserine productivities of $>80 \mathrm{~g} \mathrm{~L}^{-1} \mathrm{~d}^{-1}$ under proof of concept conditions. This compares favorably with reported fermentation processes that provide only between 2.9 and $6.4 \mathrm{~g}$ $\mathrm{L}^{-1} \mathrm{~d}^{-1}$ of product. ${ }^{16}$ The system comprises a simple combination of biocatalytic aldol addition and reductive amination reactions working in tandem, by using the class II pyruvate aldolase MBP-YfaU $\left(\mathrm{Mg}^{2+}\right)$ from E. coli $\mathrm{K} 12$ and an appropriate $S$ - or $R$-selective PLP-dependent transaminase available from Prozomix. Plausibly, this systems biocatalysis concept should be applicable to related pyruvate derived products by using other aldehyde acceptors for the synthesis of a large variety of other amino acids and related useful building blocks. Research toward this end is currently underway in our laboratories.

\section{EXPERIMENTAL SECTION}

Biocatalytic Cyclic Cascade Synthesis of L-Homoserine. The reaction was carried out in a Falcon tube $(50 \mathrm{~mL})$. Initial amounts of pyruvate $(2.1 \mathrm{mmol})$ and L-Ala $(4.2 \mathrm{mmol})$ were dissolved in $50 \mathrm{mM} \mathrm{Na}{ }^{+}$phosphate buffer, $\mathrm{pH}$ 7.0, containing PLP (1 mM). Then, MBP-YfaU $\left(\mathrm{Mg}^{2+}\right)$ (105 U, 10 $\mathrm{U} \mathrm{mL}^{-1}$ in the final reaction) and Prozomix TA39 (74 U, $7 \mathrm{U}$ $\mathrm{mL}^{-1}$ in the final reaction) were added. After that, formaldehyde was constantly added with a syringe pump at 0.57 $\mathrm{mmol} \mathrm{h}^{-1}\left(0.18 \mathrm{~mL} \mathrm{~h}^{-1}\right)$ over $15 \mathrm{~h}$ (representing a cumulative addition of $8.4 \mathrm{mmol}$ ). The starting reaction volume was 7.8 $\mathrm{mL}$, and the final volume was $10.5 \mathrm{~mL}$. Transformation to CbzL-homoserine lactone and purification and characterization procedures are described in the Supporting Information.

\section{ASSOCIATED CONTENT}

\section{S Supporting Information}

The Supporting Information is available free of charge on the ACS Publications website at DOI: 10.1021/acscatal.6b03181.

Materials, general procedures, protein expression and purification, enzymatic activity determination, enzymatic aldol reactions, compound characterization, and NMR spectra (PDF)

\section{AUTHOR INFORMATION}

\section{Corresponding Author}

*E-mail for P.C.: pere.clapes@iqac.csic.es.

ORCID ${ }^{\circ}$

Pere Clapés: 0000-0001-5541-4794

Notes

The authors declare no competing financial interest.

\section{ACKNOWLEDGMENTS}

This project has received funding from the European Union's Horizon 2020 research and innovation programme under grant agreement no. 635595 (CarbaZymes), the Ministerio de Economía y Competitividad (MINECO), the Fondo Europeo 
de Desarrollo Regional (FEDER) (grant no. CTQ2015-63563R to P.C.), and COST action CM1303 Systems Biocatalysis.

\section{REFERENCES}

(1) (a) Blaskovich, M. A. T. J. Med. Chem. 2016, 59, 10807. (b) Heravi, M. M.; Fathi Vavsari, V.; Eric, F. V. S.; Christopher, A. R. Adv. Heterocycl. Chem. 2015, 114, 77-145. (c) Fuqua, C.; Greenberg, E. P. Nat. Rev. Mol. Cell Biol. 2002, 3, 685-695.

(2) (a) Meffre, P. Amino Acids 1999, 16, 251-272. (b) Gomes, J.; Kumar, D. Enzyme Microb. Technol. 2005, 37, 3-18. (c) Kang, M.; Tata, M.; Vakalapudi, S.; McLaughlin, P.; Mahajan, A.; Wickard, D.; Lorbert, S. J.; Brinkhaus, F.; Peterson, J. C. Patent WO2013134625, September, 12, 2013. (d) Hateley, M.; Kobler, C.; Weckbecker, C.; Haeussner, T.; Bilz, J.; Huthmacher, K. Patent WO2007085514, August 2, 2007. (e) Lee, H. W.; Yang, Y. L.; Kim, S. Y.; Shin, Y. U.; Chang, J. S.; Um, H. W.; Goh, Y. H.; Jhon, S. H. Patent US20140296466A1, October 2, 2014.

(3) (a) Sun, Y.; Ma, C.; Fu, H.; Mu, Y.; Xiu, Z. In Bioprocessing of renewable resources to commodity bioproducts; Bisaria, V. S., Kondo, A., Eds.; Wiley: Hoboken, NJ, USA, 2014; pp 289-326. (b) Hong, K.-K.; Kim, J.; Yoon, J.; Park, H.-M.; Choi, S.; Song, G.; Lee, J.; Yang, Y.-L.; Shin, H.; Kim, J.; Cho, K.; Lee, J. J. Ind. Microbiol. Biotechnol. 2014, 41, 1517-1524. (c) Xu, J.; Saunders, C.; Green, P.; Velasquez, J. Patent EP2930244A1, October 14, 2015. (d) Chen, Z.; Geng, F.; Zeng, A.-P. Biotechnol. J. 2015, 10, 284-289.

(4) Zhu, J.; Kaufmann, G. F. Curr. Opin. Pharmacol. 2013, 13, 688698.

(5) (a) Qin, T.; Hu, X.; Hu, J.; Wang, X. Biotechnol. Appl. Biochem. 2015, 62, 563-573. (b) Hirasawa, T.; Shimizu, H. Curr. Opin. Biotechnol. 2016, 42, 133-146. (c) Wendisch, V. F.; Jorge, J. M. P.; Pérez-García, F.; Sgobba, E. World J. Microbiol. Biotechnol. 2016, 32, 1-10. (d) Leuchtenberger, W.; Huthmacher, K.; Drauz, K. Appl. Microbiol. Biotechnol. 2005, 69, 1-8. (e) Ikeda, M. In Microbial Production of l-Amino Acids; Faurie, R., Thommel, J., Bathe, B., Debabov, V. G., Huebner, S., Ikeda, M., Kimura, E., Marx, A., Möckel, B., Mueller, U., Pfefferle, W., Eds.; Springer: Berlin, Heidelberg, 2003; pp 1-35.

(6) Fessner, W.-D. New Biotechnol. 2015, 32, 658-664.

(7) (a) Ellis, D. I.; Goodacre, R. Curr. Opin. Biotechnol. 2012, 23, $22-$ 28. (b) Man, Z.; Xu, M.; Rao, Z.; Guo, J.; Yang, T.; Zhang, X.; Xu, Z. Sci. Rep. 2016, 6, 28629.

(8) (a) Sehl, T.; Hailes, H. C.; Ward, J. M.; Wardenga, R.; von Lieres, E.; Offermann, H.; Westphal, R.; Pohl, M.; Rother, D. Angew. Chem., Int. Ed. 2013, 52, 6772-6775. (b) Simon, R. C.; Richter, N.; Busto, E.; Kroutil, W. ACS Catal. 2014, 4, 129-143.

(9) Hift, H.; Mahler, H. R. J. Biol. Chem. 1952, 198, 901-914.

(10) (a) Hansen, B. A.; Lane, R. S.; Dekker, E. E. J. Biol. Chem. 1974, 249, 4891-4896. (b) Nozaki, H.; Kuroda, S.; Watanabe, K.; Yokozeki, K. Appl. Environ. Microbiol. 2008, 74, 7596-7599.

(11) (a) Clapés, P.; Joglar, J. In Modern Methods in Stereoselective Aldol Reactions; Mahrwald, R., Ed.; Wiley: Chichester, U.K., 2013; pp 475-528. (b) Clapés, P.; Garrabou, X. Adv. Synth. Catal. 2011, 353, 2263-2283. (c) Coincon, M.; Wang, W.; Sygusch, J.; Seah, S. Y. K. J. Biol. Chem. 2012, 287, 36208-36221. (d) Baker, P.; Seah, S. Y. K. J. Am. Chem. Soc. 2012, 134, 507-513.

(12) (a) Rea, D.; Hovington, R.; Rakus, J. F.; Gerlt, J. A.; Fülöp, V.; Bugg, T. D. H.; Roper, D. I. Biochemistry 2008, 47, 9955-9965. (b) Griffiths, J. S.; Cheriyan, M.; Corbell, J. B.; Pocivavsek, L.; Fierke, C. A.; Toone, E. J. Bioorg. Med. Chem. 2004, 12, 4067-4074.

(13) Liu, J.-W.; Boucher, Y.; Stokes, H. W.; Ollis, D. L. Protein Expression Purif. 2006, 47, 258-263.

(14) (a) Hixon, M.; Sinerius, G.; Schneider, A.; Walter, C.; Fessner, W.-D.; Schloss, J. V. FEBS Lett. 1996, 392, 281-284. (b) Wang, W.; Seah, S. Y. K. Biochemistry 2005, 44, 9447-9455.

(15) Tufvesson, P.; Jensen, J. S.; Kroutil, W.; Woodley, J. M. Biotechnol. Bioeng. 2012, 109, 2159-2162.

(16) (a) Plachý, J.; Ulbert, S.; Pelechová, J.; Krfmphanzl, V. Folia Microbiol. 1985, 30, 485-492. (b) Livshits, V. A.; Zakataeva, N. P.; Aleshin, V. V.; Belareva, A. V.; Tokmakova, I. L. Patent US 6,303,348
B1, October 16, 2001. (c) Livshits, V. A.; Doroshenko, V. G.; Mashko, S. V.; Akhverdian, V. Z.; Kozlov, Y. I. Patent US6,960,455 B2, November 1, 2005. 